in opting for 'paralectotype'. Is 'lectoparatype' not better to indicate 'a specimen chosen to be a paratype'? What we are referring to is not a sort of lectotype but a sort of paratype, one created by a lectotypification. 'Paralectotype' would imply to me some obscure sort of lectotype.

References

Frizzell, D. L. 1933. Terminology of types. Amer. Midl. Nat. 14: 637-668.

Hansen, H. V. and O. Seberg. 1984. Paralectotype, a new type term in botany. Taxon 33: 707-711.

\title{
NOMENCLATURAL ASSESSMENT OF GONIOTRICHUM KÜTZING, ERYTHROTRICHIA ARESCHOUG, DICONIA HARVEY, AND STYLONEMA REINSCH (RHODOPHYTA)
}

Michael J. Wynne'

\section{Summary}

Goniotrichum Kützing (1843) and Erythrotrichia Areschoug (1850), both being based on Conferva ceramicola Lyngbye (1819), must be regarded as nomenclatural synonyms. Since Erythrotrichia is a conserved name, Goniotrichum is automatically rejected. Diconia Harvey (1849), a taxonomic synonym of Goniotrichum, is rejected as invalid. Stylonema Reinsch (1875) becomes available to accommodate species formerly placed in Goniotrichum: $S$. cornu-cervi Reinsch, S. alsidii (Zanard.) Drew, and $S$. subcoeruleum (Dangeard) Wynne, comb. nov.

On the basis of Article 10.1 of the Sydney Code (Voss et al., 1983) problems have arisen anew in reference to the red algal genera Goniotrichum Kützing (1843) and Erythrotrichia Areschoug (1850), even though the nomenclatural delineation of these two genera has already generated much discussion in the past (Agardh, 1883; Drew, 1956; Drew and Ross, 1965). The essence of the problem is that it is unavoidable to regard these two genera as nomenclatural synonyms in that both are based on the name Conferva ceramicola Lyngbye (1819).

It is useful to reiterate the fact that the algae traditionally assigned to these two genera are clearly distinguishable. In fact, current schemes of classification universally place the genera in different orders of the Bangiophycidae (or Bangiophyceae) of the Rhodophyta. As Drew (1956) clearly pointed out, members of both genera are usually small epiphytes, with uniseriate or multiseriate organizations, occurring on larger seaweeds or seagrasses. The cells in both genera contain a single stellate chromatophore. Many differences can be elucidated. Thalli in Goniotrichum are composed of simple or pseudodichotomously branched pseudofilaments, which are attached to the substratum by an unmodified basal cell. The cells are embedded in a mucilaginous sheath, and reproduction takes place by the transformation of an entire vegetative cell into a monosporangium (Kornmann and Sahling, 1977). The monospore is released by either moving through the surrounding sheath or by the dissolution of the sheath. Thalli of Erythrotrichia are composed of filaments in which the cells have firmer walls than in Goniotrichum. The thalli may be uniseriate, multiseriate, or slightly foliose expanses, and attachment is more elaborate than in Goniotrichum, namely, by rhizoidal outgrowths from one or more basal cells or by a pseudoparenchymatous basal disc. Reproduction in Erythrotrichia occurs by the oblique divison of a vegetative cell, resulting in one of the products of division being cut off as the monosporangium and its contents being released as a monospore (Kornmann and Sahling, 1977). Goniotrichum is usually placed in the Goniotrichales or the Porphyridiales s.l. of Feldmann (1955) (Ardré, 1970; John et al., 1979; Garbary et al., 1980a), whereas Erythrotrichia is usually placed in the Bangiales (Dixon, 1982) or the Compsopogonales (Bold and Wynne, 1985), which includes the Erythropeltidales of Garbary et al. (1980a), the latter now being considered a synonym of Skuja's (1939) Compsopogonales.

The salient events in the relationship of the generic names Goniotrichum and Erythrotrichia follow.

1) Goniotrichum was described by Kützing (1843) and based on Conferva ceramicola Lyngbye (1819).

\footnotetext{
University of Michigan, Ann Arbor, MI 48109, U.S.A.
} 
But as several authors (e.g., Agardh, 1883; Drew and Ross, 1965) have subsequently pointed out, the material that Kützing had "in hand" was not congeneric with Lyngbye's type.

2) Erythrotrichia was introduced by Areschoug (1850) as a (superfluous) substitute name for Goniotrichum and Ceramicola, the latter having been established by Örsted (1844) and also based on Conferva ceramicola of Lyngbye. Erythrotrichia contained the single species E. ceramicola (Lyngb.) Aresch.

3) While maintaining both Goniotrichum and Erythrotrichia, J. Agardh (1883) made an attempt to "reform" Goniotrichum. He demonstrated that Conferva carnea Dillwyn (1807) was an earlier taxonomic synonym of Conferva ceramicola Lyngbye, and he designated E. carnea (Dillw.) J. Ag. to be the correct name of the type of Erythrotrichia. Agardh also designated Bangia elegans Chauvin (1842) the type of Kützing's Goniotrichum, the combination $G$. elegans having previously been made by Zanardini (1847).

4) Howe (1914) recognized Bangia alsidii Zanardini (1839) to be an earlier taxonomic synonym of Goniotrichum elegans (Chauv.) Zanard. and G. ceramicola sensu Kützing. In a footnote Howe (1914, p. 75) anticipated the possible outcome that is the thrust of the present article, namely, that if the generic name Goniotrichum is ever to be interpreted strictly according to its alleged type, it would result in Goniotrichum and Erythrotrichia becoming nomenclatural synonyms. Howe also stated that the next available name for what had been called Goniotrichum would apparently be Diconia of Harvey (1849).

5) Drew (1956) presented the next in-depth analysis of the nomenclatural problems concerning Goniotrichum and Erythrotrichia. She was able to confirm that the Lyngbye type specimen of Conferva ceramicola is the same taxon as that called Erythrotrichia ceramicola (Lyngb.) Aresch., i.e., E. carnea (Dillw.) J. Ag. Basing her conclusions on the citation method of typification, Drew also stated that Goniotrichum of Kützing and Erythrotrichia of Areschoug must be regarded as nomenclatural synonyms, and according to the Code the older name should be the legitimate one. Prior to Drew's publication, however, Erythrotrichia had been approved (Paris, 1954) as a Nomen Genericum Conservandum, having been conserved against the taxonomic synonym Porphyrostromium Trevisan (1848) (Silva, 1952). [Note: Garbary et al. (1980a) are incorrect in indicating that Porphyrostromium is a synonym of Bangia.] Drew (1956) correctly noted that Erythrotrichia would be automatically conserved also against Goniotrichum because the two generic names are nomenclatural synonyms (Art. 14.4).

6) Ross (in Drew and Ross, 1965) presented a detailed account of the difficulties in the delineation of these genera, and he seemed to have resolved the dilemma by typifying Goniotrichum on the basis of Kützing specimen: "This material is the type of Kützing's genus." Thus, Ross was able to recognize both Erythrotrichia as correct as a result of conservation and also Goniotrichum Kütz. as correct for the genus so called by J. Agardh (1883) and most subsequent phycologists. Ross' interpretation, however, is no longer tenable in light of Article 10.2 of the Sydney Code. The type of Goniotrichum is the type of the name Conferva ceramicola Lyngbye, not the specimen Kützing actually had "in hand" when he described the genus.

7) The present treatment, in accordance with the Sydney Code, is in agreement with Drew's (1956) interpretation. The one issue is in regard to selecting the genus to accommodate these taxa that had formerly been placed in Goniotrichum: Diconia Harvey (1849) or Stylonema Reinsch (1875). Howe (1914) had indicated Diconia as appropriate, and Silva in Farr et al. (1979) treated Diconia as a validly published name. Drew (1956), on the other hand, dismissed Diconia as invalid and selected Stylonema. Drew's treatment is here regarded as correct: Diconia cannot be considered as validly published. Harvey (1849) assigned B. elegans Chauvin, a species illustrated in Harvey's Phycologia Britannica (1846-1851, pl. ccxlvi), to Bangia with a query. Harvey stated: "This plant can hardly remain in Bangia, and will probably form the type of a new genus, to which the name Diconia . . may be given..." This name was clearly provisional and not accepted by Harvey, and thus Article 34.1(a) applies.

Therefore, the taxa that are currently being placed in Goniotrichum are re-assigned to Stylonema. The type of the generic name is $S$. cornu-cervi Reinsch (1875). Since Bangia elegans and Goniotrichum alsidii are accepted to be taxonomic synonyms (Howe, 1914; Feldmann, 1942; Drew, 1956; Dixon and Irvine in Parke and Dixon, 1976; Garbary et al., 1980b), S. alsidii (Zanard.) Drew is treated as a second species. A third species is transferred to the genus:

Stylonema subcoeruleum (Dangeard) Wynne, comb. nov. Basionym: Goniotrichum subcoeruleum Dangeard, Botaniste 51, p. 8, pl. VI, figs. 7 \& 8 (1968). 
A fourth species, Goniotrichum humphreyi Collins (1901), is sometimes accepted in the genus (e.g., Tanaka, 1952), but it was transferred to Bangiopsis Schmitz (1896) by Hamel (1929). Bangiopsis humphreyi has been regarded as a later taxonomic synonym of Bangiopsis dumontioides (Crouan in Maze \& Schramm) Krishnamurthy by Krishnamurthy (1957).

I am grateful to Prof. Edward G. Voss for nomenclatural advice.

\section{References}

Agardh, J. G. 1883. Till Algernes Systematik. VI. Ulvaceae. Lunds Univ. Arsskr. 19:1-177 + [4], 4 pls.

Ardré, F. 1970. Contribution à l'étude des algues marines du Portugal. I-La flore. Portug. Acta Biol. (B) 10: 1-423 + [1], 56 pls.

Areschoug, J. E. 1850. Phycearum, quae in maribus scandinaviae crescunt, enumeratio. Nova Acta R. Soc. Scient. upsal. 14: 385-454, 3 pls.

Bold, H. C. and M. J. Wynne. 1985. Introduction to the algae: Structure and reproduction. 2 nd edit. Prentice-Hall, Inc., Englewood Cliffs, xvi +720 pp.

Chauvin, J. F. 1842. Recherches sur l'organisation, la fructification et la classification de plusieurs genres d'algues, avec la déscription de quelques espèces inédites ou peu connues. Caen.

Collins, F. S. 1901. The algae of Jamaica. Proc. Amer. Acad. Arts and Sci. 37: 231-270.

Dangeard, P. 1968. Recherches sur quelques Bangiophycées (Protofloridées). Botaniste 51: 5-57.

Dillwyn, L. W. 1807. British Confervae .... Fasciculus 12, text and plates 82-87. London.

Dixon, P. S. 1982. Rhodophycota. In: S. P. Parker (ed.), Synopsis and classification of living organisms, Vol. 1, pp. 61-79. McGraw-Hill Book Co., New York.

Drew, K. M. 1956. Conferva ceramicola Lyngbye. Bot. Tidsskr. 53: 67-74. and R. Ross. 1965. Some generic names in the Bangiophycidae. Taxon 14: 93-99.

Farr, E. R., J. A. Leussink and F. A. Stafleu (eds.). 1979. Index nominum genericorum (plantarum). 3 vols. Regnum veget. 100, 101, 102. Bohn, Scheltema and Holkema, Utrecht.

Feldmann, J. 1942. Les algues marines de la Côte des Albères. IV. Rhodophycées. Paris, pp. 199372.

-1955. Un nouveau genre de Protofloridée: Colacodictyon, nov. gen. Bull. Soc. Bot. Fr. 102: 23-28.

Garbary, D. J., G. I. Hansen and R. F. Scagel. 1980a. A revised classification of the Bangiophyceae (Rhodophyta). Nova Hedw. 33: 145-166.

and - 1980b. The marine algae of British Columbia and northern Washington: Division Rhodophyta (red algae), class Bangiophyceae. Syesis 13: 137-195.

Hamel, G. 1929. Contribution à la flore algologique des Antilles. Ann. Crypt. Exotique 2: 53-58.

Harvey, W. H. 1846-1851. Phycologia britannica. Vols. I-IV. London.

1849. A manual of the British marine algae. 2nd edit. J. van Voorst, London, xii +252 pp.

Howe, M. A. 1914. The marine algae of Peru. Mem. Torrey Bot. Club 15: 1-185, 66 pls.

John, D. M., J. H. Price, C. A. Maggs and G. W. Lawson. 1979. Seaweeds of the western coast of tropical Africa and adjacent islands: A critical assessment. III. Rhodophyta (Bangiophyceae). Bull. Br. Mus. (Nat. Hist.), Bot. Ser. 7: 69-82.

Kornmann, P. and P.-H. Sahling. 1977. Meeresalgen von Helgoland. Benthische Grün-, Braun und Rotalgen. Helgoländer Wiss. Meeresunters. 29: 1-289.

Krishnamurthy, V. 1957. The genus Bangiopsis Schmitz from South India. Phytomorphology 7: 102-112.

Kützing, F. T. 1843. Phycologia generalis oder Anatomie, Physiologie und Systemkunde der Tange. Brockhaus, Leipzig.

Lyngbye, H. C. 1819. Tentamen hydrophytologiae danica .... Schultz, Copenhagen.

Örsted, A. S. 1844. De regionibus marinis. Elementa topographiae historiconaturalis freti Öresund. Diss. Inaug. Havniae, 88 pp., 2 pls.

Parke, M. and P. S. Dixon. 1976. Check-list of British marine algae-third revision. J. Mar. Biol. Assn. U.K. 56: 527-594.

Reinsch, P. F. 1875. Contributiones ad algologiam et fungologiam. Vol. 1. $103+$ [1] pp. Leipzig.

Schmitz, F. 1896. Bangiaceae. In: A. Engler and K. Prantl (eds.), Die natürlichen Pflanzenfamilien, Vol. 1, pp. 305-316.

Silva, P. C. 1952. A review of nomenclatural conservation in the algae from the point of view of the type method. Univ. Calif. Publ. Bot. 25: 241-324. 
Skuja, H. 1939. Versuch einer systematischen Einteilung der Bangioideen oder Protoflorideen. Acta Horti Bot., Univ. Latv. 11/12: 23-40.

Tanaka, T. 1952. The systematic study of the Japanese Protoflorideae. Mem. Fac. Fish., Kagoshima Univ. 2(2): 92 pp., 23 pls.

Trevisan, V. B. A. 1848. Saggio di una monografia della alghe coccotalle. Padua, 112 pp.

Voss, E. G. et al. (eds.) 1983. International code of botanical nomenclature, adopted by the Thirteenth International Botanical Congress, Sydney, August 1981. Regnum veget., 111. Bohn. Scheltema and Holkema, Utrecht.

Zanardini, G. A. M. 1839. Biblioteca italiana 96: 134-137. 1847. Notizie intorno alle cellulari marine delle legune e de' litoral di Venezia. Atti Adunanze I, R. Ist. Veneto Sci., Lett. Arti 6: 185-262.

\title{
NOMENCLATURAL READJUSTMENTS IN MEXICAN JUNIPERUS (CUPRESSACEAE)
}

\author{
Marshall C. Johnston'
}

\section{Summary}

The specific name Juniperus monticola used in recent revisions is not correct according to the International Code of Botanical Nomenclature. The name Juniperus sabinoides is restored for this species. Three forms are retained. One form requires a new name, J. s. forma monticola M. C. Johnst. One requires a new combination, $J$. $s$. forma orizabensis (Martínez) M. C. Johnst.

Martinez (1946: 78) published a new name Juniperus monticola Martínez to replace Schlechtendal's 1838 name $J$. tetragona because of the existence of the prior $J$. tetragona Moench, 1794. At the same time Martinez included in the synonymy of one of his forms of $J$. monticola the validly published pre-1946 specific name Cupressus sabinoides H.B.K., 1817. Martinez (1946: 86) explains that Sprengel in 1826 based his $J$. mexicana on $C$. sabinoides, and that therefore Sprengel's name was superfluous when published. It is not clear from Martinez's exposition why he felt unable to restore the 1817 epithet to the species as a whole. His justification, which does not appear to be germane under the Code either then or now, stated that the type-specimen of $C$. sabinoides, from the Cofre de Perote, Veracruz, does not pertain to the typical form of his $J$. monticola, but instead to $J$. monticola forma compacta Martinez. Zanoni and Adams (1979) followed Martinez's nomenclature for this species.

The International Code of Botanical Nomenclature is clear that the correct nomenclature for this species, using the system of Martínez and of Zanoni and Adams should be as follows:

Juniperus sabinoides (H.B.K.) Nees, Linnaea 19: 706. 1847.

With three forms as follows:

1. Juniperus sabinoides forma sabinoides.

Cupressus sabinoides H.B.K., Nov. Gen. Sp. Pl. 2: 3. 1817.

J. mexicana Sprengel, Syst. Veg. 3: 909. 1826, nom. superfl.

J. monticola forma compacta Martínez, Anal. Inst. Biol. Méx. 17: 87. 1946.

2. Juniperus sabinoides forma monticola (Martinez) M. C. Johnst., forma nov., based on J. monticola Martinez.

J. tetragona Schlecht., Linnaea 12: 495. 1838, non Moench, Meth. Pl. 699. 1794.

J. monticola Martínez, Anal. Inst. Biol. Méx. 17: 79. 1946.

1 Department of Botany and Plant Resources Center, The University of Texas at Austin, Austin, TX 78712, U.S.A. 